\title{
DOES FINANCIAL FLEXIBILITY ENHANCE FIRM VALUE? A COMPARATIVE STUDY BETWEEN DEVELOPED AND EMERGING COUNTRIES
}

\author{
Seda BILYAY-ERDOGAN $\mathbb{D}^{*}$ \\ Department of International Trade and Finance, Faculty of Management, Kadir Has University, Istanbul, Turkey
}

Received 9 May 2020; accepted 7 July 2020

\begin{abstract}
This paper investigates the effect of financial flexibility on firm value, on a comparative basis between developed and emerging countries in Europe. Our dataset covers 4,334 companies from 15 developed and 1,436 companies from 6 emerging countries in Europe for the period between 2000 and 2016. First, depending on companies' maintenance of leverage that is below-predicted levels for a successive number of years, I identify the financially flexible companies in the sample. Second, I examine whether financial flexibility affects firm value. Our results demonstrate that firms' financial flexibility positively contributes to firm value in all estimations. Furthermore, this study presents unprecedented evidence that the effect of financial flexibility on firm value is more significant for emerging countries when compared to developed countries in Europe. Moreover, I demonstrate for the first time that firm characteristics, including firm size and age, which proxy for asymmetric information within a company, negatively moderate the relationship between flexibility and firm value. Managers, both in developed and in emerging countries, who aim to surge their firm value up, should give importance to the maintenance of financial flexibility in their capital structure decisions. Last, managers of relatively smaller and younger companies should put more emphasis on becoming financially flexible if they want to improve their firms' value.
\end{abstract}

Keywords: financial flexibility, firm value, leverage, emerging and developed countries, GMM.

JEL Classification: G3, G30, G32.

\section{Introduction}

The conventional theoretical literature on corporate finance begins with Modigliani and Miller's $(1958,1961)$ irrelevance theorem. They assume that capital markets are perfect with no financing frictions, so companies can invest in all the profitable projects and amend their financial standing to adjust to unanticipated events while capturing growth opportunities. In such cases, it is not a necessity for companies to have financial flexibility (FF). Nevertheless, in reality, capital markets are not perfect, where the associated costs of financing from external sources rise and therefore, FF emerges as a significant concept.

With their survey conducted with CFOs all around the world, Graham and Harvey (2001) contend that finance executives consider being financially flexible as the most important consideration of their financial choices. The findings of surveys carried out with CFOs from Europe by Brounen et al. (2006) and Bancel and Mittoo (2004) are in line with Graham and Harvey's (2001) outcome. Moreover, according to Denis (2011), FF is a major concern for managers, confirming the findings of the surveys stated above. Financial flexibility is significant for companies, not only because flexible companies have the capability to evade financial distress and its associated costs in a negative shock situation, but also because companies can fund investments when profitable opportunities arise, mitigating complications of underinvestment that could arise from restricted access to capital (Erdogan, 2019).

Despite its significance, until recently, researchers have not concentrated on this topic, mainly because financial flexibility is not directly quantifiable and therefore difficult to measure. While a firm can create flexibility through various means, recently researchers have agreed on the terms "spare borrowing power" to refer to financial flexibility because it is possible for companies to access external capital markets easily only if they have adequate spare debt capacity (SDC) (Marchica \& Mura, 2010; DeAngelo et al., 2011).

In the financial flexibility literature, a number of empirical studies has been conducted analyzing the effects

${ }^{*}$ Corresponding author. E-mail: seda.erdogan@khas.edu.tr 
of FF: However, while Marchica and Mura (2010) and Ferrando et al. (2017) concentrate only on the developed countries in Europe, Yung et al. (2015) analyze only the emerging countries in the world and Arslan-Ayaydin et al. (2014) analyze a few countries in Asia. Nonetheless, in terms of availability of external financing and the development level of their capital markets, a significant difference is expected to exist between developed and emerging countries, which leads us to expect FF to be more important for emerging countries. However none of the studies conducted so far have done a comparative analysis between developed and emerging countries, which constitutes an important research gap that this study aims to fulfill. Moreover, none of the studies conducted so far have analyzed the moderating role firm characteristics, including firm size and age, play in the association between FF and firm value, which is another research gap to be fulfilled with this empirical study.

The prime target of this study is to research the impact of $\mathrm{FF}$ on value of companies in general. Second purpose of this study is to compare FF's impact on firm value between developed and emerging countries. Last, this paper aims to comprehend whether firm characteristics, including firm size and age moderates the relationship between FF and firm value.

In this context, after categorizing companies in the dataset as FF or not depending on their spare borrowing capacity, effect of FF on firm value is empirically analyzed. The dataset covers firms from 15 developed and 6 emerging countries in Europe, comprised of 4,334, and 1,436 publicly quoted firms respectively, for the 17 -years between 2000 and 2016. Using panel data, all estimations in this empirical study are conducted with Generalized Method of Moments (GMM).

In the first part of the analysis, firms are categorized as FF or not, based on estimation of a leverage equation, following Ferrando et al. (2017). The residuals of the leverage equation is expected to cover the systematic discrepancy within approximated levels of leverage and their actual levels. The negative deviation within the predicted target levels of leverage and actual ones indirectly captures the demand for FF (Ferrando et al., 2017). Accordingly, I categorize a firm as $\mathrm{FF}$ if its' leverage is conservative for three successive years ( 2,4 and 5 successive years are also calculated). The findings suggest that based on three successive years of below predicted leverage, while almost $31 \%$ of the companies in developed countries in my sample are FF, only $16 \%$ in emerging countries are FF.

In the second part, I provide empirical evidence that, FF positively and significantly affects firm value in all estimations, within a range of $7 \%-9 \%$ in developed countries and a range of $17 \%-26 \%$ in emerging countries, implying that no matter where a company is located (whether developed or emerging), being FF helps them improve their firm value. Moreover, with these results, I provide unprecedented and novel evidence that the impact of flexibility on value of companies is more substantial for emerging countries than for developed countries, suggesting that the companies in emerging countries should give extra importance to staying flexible if they want to improve their firm value. Finally, in order to proxy for information asymmetries in companies, two firm characteristics, firm age and size, are employed as moderator factors for the association between FF and firm value. For the first time, to the best of our knowledge, the findings of this study provide evidence that firm age and size negatively moderate the relationship between FF and firm value, such that the effect of FF on firm value decreases as a company gets bigger and older.

Last, several robustness tests are conducted within the scope of this study, including the implementation of different definitions of FF, the findings of which demonstrate that FF positively and significantly affects firm value in all estimations, suggesting that even if different measurement techniques are implemented for FF, it positively affects value of companies.

\section{Theoretical background}

Firm value is a broad, multidimensional concept, measurement of which is rather comprehensive with no universally accepted and consistent methods, with different approaches using different techniques to apprehend how companies succeed to create value not only for their shareholders, but also for their stakeholders (Meehan et al., 2011). Researchers have posed several theoretical explanations for firm value, however each has been identified with flaws (Meehan et al., 2011), which is why the concepts provided are best approximations of firm value and they do not reveal a practical and universal approach for calculating it, resulting in the concept of firm value being complex to analyze. Notwithstanding this, different theories are developed trying to explain firm value from different angles.

Traditionally, firm value is thought to be only connected to shareholders' value, wherein to improve firm value, shareholders' value is required to be maximized. However, recently, this traditional concept of maximization of shareholders' value is often criticized by researchers, who claim that value of companies should take into account all groups of stakeholders, not only shareholders (Lonkani, 2018).

Researchers try to explain firm value through various ways and analyzing agency problems and corporate governance principles is one of them. Agency problems usually result from managers' tendency to engage in their own interest instead of the shareholders', who are usually dispersed and hence cannot monitor and control the actions of managers (Jensen \& Meckling, 1976). In such cases, corporate governance implementations assist develop systems to improve firms' transparency, leading to success and ultimately to an upsurge in corporate value. On the other hand, good corporate governance requires companies to incur additional monitoring and auditing costs. Notwithstanding the benefits, it is not clear whether better governance definitely results in higher firm value, as 
the costs born from implementation of governance principles may offset the benefits (Bruno \& Claessens, 2007).

On the other hand, there is a stream of literature on firm value explained by optimal financing of firms. The impact of leverage on firm value constitutes a very significant dispute in the corporate finance literature, starting with Modigliani and Miller $(1958,1961)$, who argue that amount of leverage a company gets is irrelevant to firm value, assuming that capital markets are perfect, with no financing frictions and hence no need for FF. Following the irrelevance theorem, researchers started to shift their focus to more realistic scenarios, in which capital market imperfections do exist, in relation to which leverage emerges as a significant factor related to raising external capital because firms in imperfect capital markets cannot always have adequate financial opportunities to invest in profitable projects. After irrelevance theorem, two classical theories (trade-off theory and pecking order hypothesis) have predominated the literature on capital structure. According to trade-off theory, through trading off the benefits of debt with associated costs, firms reach an optimal level of debt-equity balance. On the other hand, pecking order theory set forth by Myers (1984) asserts that managers try to minimize adverse selection costs associated to external financing and so companies follow hierarchical order in financing favoring internal funds over equity. According to Myers (1984) and Myers and Majluf (1984), companies with higher asymmetric information are faced with higher costs associated to equity, resulting in these companies having suboptimal investments, with a declining impact on firm value. Myers (1984) also argues that debt financing can be value enhancing based on the extent of asymmetric information, suggesting that asymmetric information and leverage interact in a dynamic way to impact firm value.

All in all, research shows that leverage affects firm value in two ways: First, tax deductibility of interest as opposed to dividend payments improves firm value until increased chances of bankruptcy costs offsets its benefits (Modigliani \& Miller, 1963). Second, the conflicts between shareholders and managers alter the impact leverage has on firm value. According to Myers (1977), some companies stop themselves from undertaking positive NPV projects due to potential increase in their debt obligations and hence companies with growth opportunities sacrifice getting debt despite its tax advantages. Hence, research demonstrates that financing with debt can either be value increasing or decreasing (Aggarwal \& Zhao, 2007), such that leverage can increase value due to its tax advantage and assistance in mitigating the overinvestment problem or it can decrease value due to the surge up in bankruptcy costs and deteriorate the underinvestment problem.

H. DeAngelo and L. DeAngelo (2007) argue that literature on capital structure does not have an empirically sustainable theory. Trade-off theory ignores the significance of FF, which leads it to empirically underperform and therefore it is being criticized due to its inability to explain observed debt ratios (Denis \& McKeon, 2012). Fama and French (2005) state that neither trade-off nor pecking order theories can shed light on real-world debt choices of companies. Scholars explain empirically underperforming capital structure theories by citing the tendency of firms to desire keeping FF as an extra capacity for additional borrowing (H. DeAngelo \& L. DeAngelo, 2007, Marchica \& Mura, 2010; Denis \& McKeon, 2012; Gamba \& Triantis, 2008). Hence, the concept of FF offers explanations for the dilemmas raised in the capital structure literature, suggesting that financial flexibility can constitute an essential "missing link" to connect the propositions of existing capital structure theories to companies' observed behavior.

In line with this, H. DeAngelo and L. DeAngelo (2007) establish a theory to explain firms' empirical behavior in their capital structure decisions, providing evidence that firms' financial decisions are influenced and made with the need to maintain FF. H. DeAngelo and L. DeAngelo (2007) argue that companies should optimally preserve low borrowing rates in most periods to be able to maintain the possibility of borrowing in times where the requirement for capital needs is high, arguing that financial flexibility is the significant component that attaches what the theories in capital structure literature proposes to how companies behave. Moreover, Gamba and Triantis (2008) make a theoretical contribution that companies with flexibility are anticipated to possess surplus value compared to non-flexible firms.

On the empirical side, Marchica and Mura (2010) and Ferrando et al. (2017) state that flexible companies demonstrate better investment capability than non-flexible firms in the UK and in Europe, respectively. Consistent with preceding papers, Rapp et al. (2014) argue that flexibility considerations shape corporate financial policies in US. Finally, Yung et al. (2015) and Arslan-Ayaydin et al. (2014) demonstrate that FF positively affects capital expenditures of companies in addition to firm performance in Asian countries. As can be analyzed from this review, only a few of the empirical studies have analyzed emerging markets (Yung et al., 2015) and none of them have done a comparative analysis. In this context, the primary purpose of the present study is to understand the impact of FF on firm value both in developed and emerging countries, following which the second purpose is to empirically compare FF's impact on firm value between emerging and developed countries. The final purpose of this study is to comprehend the impact of firm characteristics on the association between FF and firm value. In order to understand and test the significance of these relationships, four different hypothesis are built, the explanations and rationale of which are given in detail in Section 2.4 - Hypothesis Development Section.

\section{Empirical design}

The purpose of this analysis is to find out whether FF affects firm value and compare its impact in developed and emerging countries. The developed countries' dataset 
includes the entire list of countries in the Morgan Stanley Capital International (MSCI) World Index for Europe, while emerging countries' dataset includes the entire list of countries listed in the MSCI Emerging Markets Index for Europe. ${ }^{1}$ I download the market and accounting data of the companies in these countries from Thomson Reuters Eikon and Datastream databases.

\subsection{Sample selection procedure}

In the selected countries, I begin with the entire universe of publicly listed companies. I analyze the time frame between 2000 and 2016. I lose a year of observations due to the calculation of some variables (ex: sales growth). Table 1 summarizes the sample selection procedure. Following the data filtering process, the unbalanced panel consists of 4.334 firms and 73.678 observations for the developed and 1.436 firms and 24.412 observations for the emerging countries.

Table 1. Procedure for the selection of dataset

\begin{tabular}{|l|c|c|}
\hline Number of companies in the sample & $\begin{array}{c}\text { Developed } \\
\text { Countries }\end{array}$ & $\begin{array}{c}\text { Emerging } \\
\text { Countries }\end{array}$ \\
\hline $\begin{array}{l}\text { Entire set of active \& publicly } \\
\text { quoted companies in Europe } \\
\text { (for the time period between 2000- } \\
2016)\end{array}$ & 10.959 & 2.697 \\
\hline $\begin{array}{l}\text { Exclude companies from banking, } \\
\text { insurance, real estate and financial } \\
\text { services }\end{array}$ & -4.500 & -516 \\
\hline $\begin{array}{l}\text { Exclude companies, which have less } \\
\text { than 4 years of financial data* }\end{array}$ & -1.637 & -681 \\
\hline $\begin{array}{l}\text { Exclude companies, which are not } \\
\text { listed in the major securities }\end{array}$ & -164 & -34 \\
\hline $\begin{array}{l}\text { Exclude companies, which have } \\
\text { inconsistent data (negative number } \\
\text { of shares, negative sales, etc.) }\end{array}$ & -324 & -30 \\
\hline Final Sample Size & 4.334 & 1.436 \\
\hline
\end{tabular}

Note: ${ }^{\star}$ To construct the FF dummy variable, 4 successive years of financial data is required.

\subsection{Leverage estimation model}

A clear-cut measure of FF does not exist in the literature. Marchica and Mura (2010), Yung et al. (2015) and Ferrando et al. (2017) use "Spare Debt Capacity (SDC)" to determine whether companies have financial flexibility. In order to assess whether companies have SDC, their actual level of leverage is compared to the predicted (maximum) amount of leverage companies can obtain. Ferrando et al. (2017) describe FF as an unobservable factor, which depends to a great extent on managers' valuation of future growth opportunities. FF is expected to produce a systematic gap between projected and observed levels of leverage

\footnotetext{
1 Developed countries analyzed: the UK, Switzerland, Sweden, Germany, Denmark, Finland, the Netherlands, France, Ireland, Italy, Norway, Belgium, Portugal, Spain and Austria. Emerging countries analyzed: Turkey, Russia, Hungary, the Czech Republic, Poland, and Greece.
}

and consequently it is anticipated to be contained in the residual of the leverage regression model. Based on the methodology implemented by Marchica and Mura (2010), Yung et al. (2015) and Ferrando et al. (2017), a company has SDC if its actual leverage is less than its predicted leverage and moreover a company is FF if it has SDC for a number of successive years. In this context, the gap between the actual and predicted leverage of companies indirectly contain firms' FF. The predicted level of leverage is obtained through getting the fitted values from the leverage regression model, which is to be compared to actual leverage a company has. Fitted values of leverage are the maximum leverage a company can get, and accordingly if a company's fitted (predicted) values of leverage is greater than its actual leverage, that company has SDC (Marchica \& Mura, 2010; Yung et al., 2015; Ferrando et al., 2017)

Hence, in order to determine whether a company has SDC, first its' predicted level of leverage should be estimated through a leverage regression model. To approximate the leverage equation, I use Model 1 below following Ferrando et al. (2017):

$$
\begin{aligned}
& \text { Leverage }_{i t}=\beta_{0} \text { Leverage }_{i t-1}+ \\
& \sum_{k=1}^{K} \beta_{k} X_{k i c t}+\eta_{c}+\eta_{t}+v_{c t} .
\end{aligned}
$$

Using panel data, I estimate all models with GMM. Companies have a tendency to set a target debt to equity ratio and reach this preset capital structure: $37 \%$ of companies in US possess a flexible target capital structure level (Graham \& Harvey, 2001) and similar patterns are observed for UK (Bancel \& Mittoo, 2004). With the purpose of capturing this targeting behavior of capital

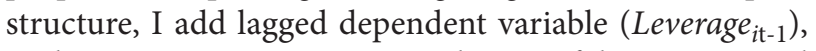
in the estimation, necessitating the use of dynamic partial adjustment leverage model. Moreover, to control for the endogeneity of the variables used in the approximation, I use GMM methodology developed by Arellano and Bond (1991). Suitable lagged regressors along with first differences of the dependent variable are used as instruments (Lemmon et al., 2008, Blundell \& Bond, 1998). While I use country fixed effect $\left(\eta_{c}\right)$ with the purpose of covering possible correlations within regressors and features specific to countries, I use time fixed effect to take into account probable macroeconomic factors, including years of economic crisis. To control for the structure of the model and the validity of the instruments, I check AR (2) test established by Arellano and Bond (1991) that examines the presence of second-order serial correlation in the firstdifference residuals. ${ }^{2}$

In the first research model (Model 1), where I estimate

\footnotetext{
2 Sargan test results are not reported as part of the typical diagnostic checks because when the sample size contains panels of dimensions similar to my sample size, instruments used in the analysis tend to be over-rejected with the Sargan test (Bond et al., 2004, Ferrando et al., 2017). Some researchers have shown the potential issue of "overfitting bias" (Bowsher, 2002). This is why only AR (2) results are reported in this analysis.
} 
a leverage regression model, the dependent variable is leverage. This regression is estimated with the inclusion of several control variables including firm size, asset tangibility, profitability, depreciation, tax shield, cash ratio and sales growth following Ferrando et al. (2017). Measures of each variable used in the leverage model are based on the study conducted by Ferrando et al. (2017) and Table 2 provides the descriptions of how these variables are measured in detail.

Table 2. Description of Variables - Leverage model

\begin{tabular}{|l|l|c|}
\hline \multicolumn{1}{|c|}{ Variable* } & \multicolumn{1}{|c|}{ Definition } & $\begin{array}{c}\text { Expected Impact } \\
\text { on Leverage }\end{array}$ \\
\hline Leverage & $\begin{array}{l}\text { Total debt (short and long } \\
\text { term) over total assets }\end{array}$ & \\
\hline Firm Size & Ln (total assets) & + \\
\hline Sales growth & $\left(\right.$ Sales $_{t}-$ Sales $\left.t-1\right) /$ Sales $_{t-1}$ & + \\
\hline Profitability & $\begin{array}{l}\text { Net income deflated by } \\
\text { total assets }\end{array}$ & - \\
\hline Tax Shield & $\begin{array}{l}\text { Total income taxes to total } \\
\text { assets }\end{array}$ & - \\
\hline Cash Ratio & $\begin{array}{l}\text { Cash and equivalents } \\
\text { scaled by total assets }\end{array}$ & + \\
\hline Depreciation & $\begin{array}{l}\text { Depreciation and } \\
\text { amortisation to total assets }\end{array}$ & $+/-$ \\
\hline $\begin{array}{l}\text { Asset } \\
\text { Tangibility }\end{array}$ & $\begin{array}{l}\text { Net fixed assets to total } \\
\text { assets }\end{array}$ & + \\
\hline
\end{tabular}

Note: ${ }^{\star}$ I winsorize entire set of variables at $1 \%$ and $99 \%$ of their own distribution.

The results of the leverage estimations for developed and emerging countries are provided in Table 3.

The results reported in Table 3 are in line with previous empirical studies (Flannery \& Rangan, 2006). In line with the expectations, size is significantly and positively associated to leverage both in developed and emerging countries, similar to Al Ani and Al Amri's (2015) findings. As a company gets bigger, they tend to be more transparent, borrow at lower costs, have lower asset volatility and hence are inclined to acquire more debt. Sales growth also positively and significantly affects leverage, as companies need increased levels of leverage to finance their growth opportunities.

On the contrary, profitability negatively affects leverage, both in emerging and developed countries, in agreement with the pecking order theory. The cash and tax levels of companies also negatively and significantly affect their leverage. Moreover, the impact of depreciation on leverage is positive in developed countries, because leverage rises due to financing requirements of increasing tangible assets, which also positively affects leverage. In contrast, depreciation negatively affects leverage in emerging countries, because for these companies, a rise in depreciation leads to reduced levels of interest deduction requirement rising from borrowing, which results in reduced levels of borrowing. Finally, the impact of tangibility on leverage is significantly positive for both developed and emerging
Table 3. Leverage model results for developed and emerging countries

\begin{tabular}{|c|c|c|}
\hline $\begin{array}{c}\text { Dependent } \\
\text { Variable: Leverage }{ }_{t}\end{array}$ & $\begin{array}{l}\text { Developed } \\
\text { Countries }\end{array}$ & $\begin{array}{l}\text { Emerging } \\
\text { Countries }\end{array}$ \\
\hline \multirow{2}{*}{ Leverage $_{t-1}$} & $0.449^{* * *}$ & $0.754^{* * *}$ \\
\hline & {$[0.000]$} & {$[0.000]$} \\
\hline \multirow{2}{*}{ Firm Size } & $0.054^{* * *}$ & $0.030^{* * *}$ \\
\hline & {$[0.001]$} & {$[0.000]$} \\
\hline \multirow{2}{*}{ Sales growth } & $0.027^{\star \star *}$ & $0.023^{* * *}$ \\
\hline & [0.009] & {$[0.000]$} \\
\hline \multirow{2}{*}{ Profitability } & $-0.145^{\star * *}$ & $-0.143^{* * *}$ \\
\hline & {$[0.000]$} & {$[0.000]$} \\
\hline \multirow{2}{*}{ Tax Shield } & $-0.185^{\star \star \star}$ & $-0.585^{\star * *}$ \\
\hline & [0.004] & [0.000] \\
\hline \multirow{2}{*}{ Cash Ratio } & $-0.087^{* * *}$ & $-0.062^{* * *}$ \\
\hline & {$[0.000]$} & [0.002] \\
\hline \multirow{2}{*}{ Depreciation } & $0.193^{\star * *}$ & $-0.627^{* * *}$ \\
\hline & {$[0.011]$} & [0.013] \\
\hline \multirow{2}{*}{ Asset Tangibility } & $0.166^{\star * *}$ & $0.043^{* \star \star}$ \\
\hline & {$[0.000]$} & {$[0.007]$} \\
\hline Observations & 40.371 & 7.581 \\
\hline No. of firms & 3.631 & 1.061 \\
\hline No. of instruments & 47 & 411 \\
\hline $\operatorname{AR}(1)$ & 0.145 & 0.000 \\
\hline $\mathrm{AR}(2)$ & 0.195 & 0.287 \\
\hline
\end{tabular}

Notes: ${ }^{*},{ }^{* *}$ and ${ }^{* *}$ denote significance at $10 \%, 5 \%$ and $1 \%$, respectively.

countries, because possessing more tangible assets in their portfolios makes it easy for companies to obtain external financing. AR (2) statistics stand at $19.5 \%$ and $28.7 \%$ for the leverage estimations of developed and emerging countries, respectively, which indicates that instruments are correctly identified and valid in both models.

\subsection{Classification of financially flexible firms}

I obtain the fitted values from the estimated leverage equation following Faulkender et al. (2012). For each separate observation within my sample, the actual levels of leverage are compared with the fitted values obtained from the leverage estimation. Actual levels of leverage represent the firms' real borrowing levels. Fitted values represent the maximum amount of borrowing a company can get with its current financial situation. If the actual values of leverage are less than the fitted values, that firm is said to have Spare Debt Capacity, suggesting that with its current financial standing the firm has the potential to receive more bank financing but has purposefully obtained less borrowing. Ferrando et al. (2017) argue undetected impact of FF result in systematic deviations within the actual and predicted levels of leverage. With the purpose of diminishing the effect of small deviations, in line with the suggestions of Ferrando et al. (2017), we require these deviations to be greater than 5\%. Moreover, in order to make sure that the 
negative deviation is neither temporary nor random, but in fact a consistent policy of the firm, a company is classified as FF if the company has SDC for at least two years (FF2). Hence, if a company has 2 successive years of SDC, FF2 is assigned as 1 and 0 otherwise. Three (FF3), four (FF4) and five (FF5) years of SDC are also considered as alternative proxies of FF throughout the analysis, with the ultimate purpose of determining whether the time span of low leverage has an impact on hypothesized relationships. FF3 is taken as the independent variable both in baseline estimations and in the robustness tests.

Table 4 shows the shares of financially flexible firms within the whole sample.

Table 4. Financially flexible firms - developed countries vs. emerging countries

\begin{tabular}{|l|c|c|c|c|}
\hline & FF2 & FF3 & FF4 & FF5 \\
\hline Developed Countries & $34.3 \%$ & $31.0 \%$ & $27.5 \%$ & $24.5 \%$ \\
\hline Emerging Countries & $25.7 \%$ & $16.3 \%$ & $9.4 \%$ & $6.0 \%$ \\
\hline
\end{tabular}

Notes: ${ }^{*} \mathrm{FF} 2$ : Financial Flexibility 2 (a firm with SDC for at least 2 consecutive periods). FF3, FF4 and FF5 can be interpreted in the same way.

While $31.0 \%$ of the firms in the developed countries has SDC for at least three years (FF3), only $16.3 \%$ of those in emerging countries were at that capacity. These results imply that the percentage of flexible firms in developed countries was almost double that of flexible firms in emerging countries (based on FF3 classification). Moreover, the drop in percentages of flexible firms is more precipitous for companies in emerging countries relative to the drop in developed countries (In developed countries $24.5 \%$ of firms are FF5 vs. in emerging countries only $6 \%$ of companies are FF5). As the consecutive number of SDC increases, the percentage of flexible companies in the whole sample (both developed and emerging countries) declines, signifying the difficulty in maintaining flexibility over longer periods of time.

\subsection{Hypothesis development: Impact of FF on firm value}

After classifying the firms in Europe as FF or not, this study investigates whether $\mathrm{FF}$ affects value of companies and furthermore compares the impact between emerging and developed countries.

Gamba and Triantis (2008) argue that companies with FF should have prime value because these companies are able to sidestep the costs of financial distress resulting from unanticipated negative events and pursue investment prospects that unexpectedly arise. Arslan-Ayaydin et al. (2014) also argue that FF gives a company the necessary skills to get over unanticipated events or even benefit from unpredicted prospects at a low cost, and their ability to meet funding needs resulting from unexpected shortfalls in their earnings enables them to avoid poor performance due to suboptimal investments. Based on these arguments,
I expect firms with FF to be valued at a premium, hypothesizing the following:

Hypothesis 1: Financial Flexibility positively affects firm value.

External financing decisions constitute a major challenge for the corporates in emerging markets, mainly because their capital markets tend to be underdeveloped (Yung et al., 2015) relative to the ones in developed markets. The presence of highly volatile capital flows in emerging countries leads companies to seek funding from external sources (Bekaert \& Harvey, 2003, Demir, 2009), results in reductions in economic growth, and weakens companies' performance (Demir, 2009). Consequently, I expect $\mathrm{FF}$ in emerging countries to enhance firm value more than it does in developed countries, because flexible companies are capable of avoiding the consequences of the negative shocks, which tend to occur more likely in emerging markets, by circumventing the higher costs associated to raising capital and also by accepting possible positive NPV projects. Accordingly, I hypothesize the following:

Hypothesis 2: Impact of FF on firm value is stronger in emerging countries compared to developed countries.

In order to test Hypothesis $1 \& 2$, firm value is taken as the dependent and FF dummy (4 different FF dummies) is taken as the independent variable (Model 2).

$$
\begin{aligned}
& \text { FirmValue }_{i t}=\gamma_{1} \text { FirmValue }_{i, t-1}+ \\
& \gamma_{2} F F_{i, t}+\sum_{k=1}^{K} \gamma_{k} X_{k i c t}+\eta_{c}+\eta_{t}+v_{c t} .
\end{aligned}
$$

Certain features of companies, including firm age and size are used in literature to proxy for potential informational asymmetries that firms may face. Based on the notion that smaller (Berger \& Udell, 2005) and younger companies (Rauh, 2006) have relatively restricted access to capital markets compared to their bigger and older counterparts and therefore have more difficulty in obtaining external financing, I expect company specific features, including, firm age and size to negatively moderate the impact of FF on value of companies. Hence, I construct Hypothesis 3 and 4 for both the developed and the emerging countries.

Hypothesis 3: Firm size negatively moderates the association between $\mathrm{FF}$ and firm value.

Hypothesis 4: Firm age negatively moderates the association between FF and firm value.

I will use Models 3 and 4 presented below to test Hypothesis 3 and 4 , respectively.

$$
\begin{aligned}
& \text { Firm Value }_{i t}=\gamma_{1} \text { Firm Value }_{i, t-1}+\gamma_{2} F_{i, t}+ \\
& \gamma_{3} F_{i, t} \times \text { Firm Size }_{i, t}+\sum_{k=1}^{K} \gamma_{k} X_{k i c t}+\eta_{c}+\eta_{t}+v_{c t} \text {; } \\
& \text { Firm Value }_{i t}=\gamma_{1} \text { Firm Value }_{i, t-1}+\gamma_{2} F_{i, t}+ \\
& \gamma_{3} F F_{i, t} \times \text { Firm Age }_{i, t}+\sum_{k=1}^{K} \gamma_{k} X_{k i c t}+\eta_{c}+\eta_{t}+v_{c t} .
\end{aligned}
$$


I estimate Models 2, 3 and 4 with GMM, to evade endogeneity and unobservable heterogeneity problems that are highlighted in previous literature. An endogeneity problem could arise, since an increase in firm value may result in a company to have higher capacity to put more leverage on their balance sheets, which could result in higher gaps between maximum and actual amount of debt a firm get obtain, hence resulting in the firm being more financially flexible. Moreover, companies are heterogeneous and there could be some features, which affect value of companies that could be hard to obtain and difficult to measure (De Miguel et al., 2004). Hence, with the intention to control a possible endogeneity and unobservable heterogeneity, I implement GMM proposed by Arellano and Bover (1995) and Blundell and Bond (1998), following Wintoki et al. (2012) and Pindado et al. (2010). Lagged firm value is also added into the equation as a regressor, following Ammann et al. (2011). Moreover, to control for unobserved heterogeneity and consequently exclude a possible omitted variable bias, I difference all variables and use them as instruments, following Lemmon et al. (2008), Ammann et al. (2011) and Blundell and Bond (1998).

\subsection{Variables}

In the second, third and fourth research models of this study (Model 2, 3 and 4), the dependent variable is firm value, which is proxied with Tobin's $\mathrm{Q}$ that is developed by Chung and Pruitt (1994) and used by many researchers, including Yung et al. (2015). The control variables used in this model are firm size, cash flow, dividend, investment, cash ratio and firm age, following Yung et al. (2015). Leverage is also added as a control variable following Lemmon

Table 5. Description of variables - firm value model

\begin{tabular}{|l|l|c|}
\hline Variable & \multicolumn{1}{|c|}{ Description } & $\begin{array}{c}\text { Predicted } \\
\text { Effect on } \\
\text { Firm Value }\end{array}$ \\
\hline Firm Value & $\begin{array}{l}\text { Tobin's Q } \\
\text { (Market value of common equity } \\
\text { + preferred stock + book value of } \\
\text { total liabilities / book value of total } \\
\text { assets })\end{array}$ & \\
\hline $\begin{array}{l}\text { Financial } \\
\text { Flexibility }\end{array}$ & $\begin{array}{l}\text { FF: } 1 \text {, if company has 2,3,4 and 5 } \\
\text { successive years of SDC, } \\
\text { FF: } 0 \text { otherwise }\end{array}$ & + \\
\hline Firm Size & Ln (total assets) & $+/-$ \\
\hline Cash Flow & EBITDA over total assets & $+/-$ \\
\hline $\begin{array}{l}\text { Dividend } \\
\text { Dummy } \\
\text { (DD) }\end{array}$ & $\begin{array}{l}\text { DD: } 1 \text {, if company distributes } \\
\text { dividends and } \\
\text { DD: } 0 \text { otherwise. }\end{array}$ & + \\
\hline Investment & $\begin{array}{l}\text { Capital expenditures to total } \\
\text { assets. }\end{array}$ & + \\
\hline Leverage & $\begin{array}{l}\text { Total debt (short and long term) } \\
\text { over total assets }\end{array}$ & $+/-$ \\
\hline Cash Ratio & $\begin{array}{l}\text { Cash and equivalents scaled by } \\
\text { total assets }\end{array}$ & $+/-$ \\
\hline Firm Age & Ln (1+ firm age) & + \\
\hline & & + \\
\hline
\end{tabular}

and Lins (2003). Measurement techniques of each variable used in the firm value model (Research models 2, 3 and 4) are constructed based on the studies of Yung et al. (2015) and Lemmon and Lins (2003), the details of which are presented in Table 5.

All in all, the variables used in the leverage model are constructed based on the methodology implemented by Ferrando et al. (2017). Since all variables used by Ferrando et al. (2017) are taken into consideration, there are no omitted variables in the leverage estimations conducted for this empirical study. On the other hand, the firm value model is constructed based on the methodology used by Yung et al. (2015) and all important variables are taken into consideration. However, Yung et al. (2015) has also added "investor protection" variable into its firm value model, in order to capture the different investor protection levels specific to different countries. In the present study, I include country fixed effect in order to take into account the different features of countries. Notwithstanding this, with the intention of comprehending the asymmetric information on a country level, investor protection can also be included in analysis in future studies.

\section{Results}

\subsection{Effect of FF on firm value: Baseline tests}

First, I analyze whether FF affects firm value. The first four columns of Table 6 and Table 7 provide the findings of developed and emerging countries, respectively. Each column represents a separate regression estimation, with the only difference between them being the FF dummy used. FF dummies range from FF2 to FF5.

In the entire set of estimations conducted for both developed and emerging countries, flexibility coefficient is positively and significantly associated to firm value, supporting Hypothesis 1. The effect of FF on value of companies is within the 7\%-9\% range in all of the four estimations for developed countries. However, the level of impact is considerably higher in emerging countries relative to the impact in developed countries. In all of the four separate regression analysis; the level of impact of FF on firm value ranges between $18.6 \%$ and $26.2 \%$ in emerging countries in comparison to the $7 \%-9 \%$ effect in developed countries. This result demonstrates the greater impact of $\mathrm{FF}$ on value of companies for emerging countries in comparison to developed countries, supporting the argument stated in Hypothesis 2.

Firm size positively and significantly affects firm value in all eight specifications (developed and emerging); because bigger companies tend to get advantage from economies of scale, lower transactions costs and improved ease of access to get external financing, all of which contribute to the rise in value of companies. Dividends are also expected to augment firm value in both datasets, because dividends tend to decrease free cash flow, which might otherwise be spent by managers in suboptimal projects and also on managers' perquisite spending and hence 
Table 6. Firm value model: Baseline regressions - Developed countries

\begin{tabular}{|c|c|c|c|c|c|c|}
\hline $\begin{array}{l}\text { Dep Var: Firm } \\
\text { Value }_{\mathrm{t}}\end{array}$ & $\begin{array}{l}(1) \\
\text { FF2 }\end{array}$ & $\begin{array}{l}(2) \\
\text { FF3 }\end{array}$ & $\begin{array}{l}(3) \\
\text { FF4 }\end{array}$ & $\begin{array}{l}(4) \\
\text { FF5 }\end{array}$ & $\begin{array}{l}(5) \\
\text { FF3 }\end{array}$ & $\begin{array}{l}(6) \\
\text { FF3 }\end{array}$ \\
\hline \multirow{2}{*}{ Firm Value $_{(t-1)}$} & $0.426^{* * *}$ & $0.428^{\star * *}$ & $0.418^{\star * \star}$ & $0.417^{\star * *}$ & $0.541^{\star * *}$ & $0.590^{\star * *}$ \\
\hline & {$[0.000]$} & {$[0.000]$} & {$[0.000]$} & {$[0.000]$} & {$[0.000]$} & {$[0.000]$} \\
\hline \multirow{2}{*}{ Firm Size } & $0.021^{\star * *}$ & $0.021^{\star * *}$ & $0.022^{\star * \star}$ & $0.022^{\star * \star}$ & $0.012^{\text {***}}$ & $0.005^{\star * *}$ \\
\hline & {$[0.000]$} & {$[0.000]$} & {$[0.000]$} & {$[0.000]$} & {$[0.002]$} & [0.019] \\
\hline \multirow{2}{*}{ Cash Flow } & $-0.383^{\star * *}$ & $-0.385^{\star * *}$ & $-0.384^{* * *}$ & $-0.398^{\star * *}$ & $-0.539^{* * *}$ & $-0.570^{\star * *}$ \\
\hline & {$[0.000]$} & {$[0.000]$} & {$[0.000]$} & {$[0.000]$} & {$[0.000]$} & {$[0.000]$} \\
\hline \multirow{2}{*}{$\begin{array}{l}\text { Dividend } \\
\text { Dummy }\end{array}$} & $0.033^{\star * *}$ & $0.035^{\star * *}$ & $0.035^{\star * \star}$ & $0.036^{\star * *}$ & $0.067^{* * *}$ & $0.068^{\star * *}$ \\
\hline & {$[0.000]$} & {$[0.000]$} & {$[0.000]$} & {$[0.000]$} & {$[0.000]$} & {$[0.000]$} \\
\hline \multirow{2}{*}{ Investment } & $0.056^{\star * *}$ & $0.058^{\star \star \star *}$ & $0.052^{\star \star *}$ & $0.051^{\star \star *}$ & $0.100^{* * *}$ & $0.113^{\star * *}$ \\
\hline & {$[0.002]$} & {$[0.001]$} & {$[0.004]$} & {$[0.005]$} & {$[0.000]$} & {$[0.000]$} \\
\hline \multirow{2}{*}{ Leverage } & $0.600^{\star * *}$ & $0.599^{\star * *}$ & $0.606^{\star * *}$ & $0.607^{\star * *}$ & $0.540^{\star * *}$ & $0.497^{\star * *}$ \\
\hline & {$[0.000]$} & {$[0.000]$} & {$[0.000]$} & {$[0.000]$} & {$[0.000]$} & {$[0.000]$} \\
\hline \multirow{2}{*}{ Cash Ratio } & $-0.144^{* * *}$ & $-0.138^{\star * *}$ & $-0.134^{\star * *}$ & $-0.141^{\star * *}$ & $-0.198^{\star * *}$ & $-0.209^{\star * *}$ \\
\hline & {$[0.000]$} & {$[0.000]$} & {$[0.000]$} & {$[0.000]$} & {$[0.000]$} & {$[0.000]$} \\
\hline \multirow{2}{*}{ Firm Age } & $0.017^{\star * *}$ & $0.016^{* * *}$ & $0.014^{* * *}$ & $0.015^{\star * *}$ & $0.025^{\star \star *}$ & $0.030^{* * *}$ \\
\hline & {$[0.000]$} & {$[0.000]$} & {$[0.000]$} & {$[0.002]$} & {$[0.000]$} & {$[0.000]$} \\
\hline \multirow{2}{*}{ FF Dummy } & $0.069^{\star}$ & $0.076^{\star *}$ & $0.086^{\star * *}$ & $0.078^{\star * *}$ & $0.161^{\star * *}$ & $0.068^{\star * *}$ \\
\hline & {$[0.067]$} & {$[0.043]$} & {$[0.008]$} & {$[0.008]$} & {$[0.000]$} & {$[0.000]$} \\
\hline \multirow{2}{*}{$\begin{array}{l}\text { FF Dummy } \times \\
\text { Firm Size }\end{array}$} & & & & & $-0.028^{* * *}$ & \\
\hline & & & & & {$[0.000]$} & \\
\hline \multirow{2}{*}{$\begin{array}{l}\text { FF Dummy } \times \\
\text { Firm Age }\end{array}$} & & & & & & $-0.020^{\star * *}$ \\
\hline & & & & & & {$[0.000]$} \\
\hline Observations & 29.249 & 28.006 & 26.702 & 25.289 & 28.006 & 28.006 \\
\hline No. of firms & 2475 & 2.474 & 2.473 & 2.472 & 2.474 & 2.474 \\
\hline $\begin{array}{l}\text { No. of } \\
\text { instruments }\end{array}$ & 205 & 329 & 319 & 307 & 70 & 71 \\
\hline $\mathrm{AR}(1)$ & 0.000 & 0.000 & 0.000 & 0.000 & 0.000 & 0.000 \\
\hline $\operatorname{AR}(2)$ & 0.395 & 0.172 & 0.191 & 0.215 & 0.291 & 0.254 \\
\hline
\end{tabular}

Notes: ${ }^{\star},{ }^{* *}$ and ${ }^{* *}$ denote significance at $10 \%, 5 \%$ and $1 \%$, respectively.

resulting in a potential decline in agency issues and an upsurge in the value of companies.

The impact of cash flow on firm value is significantly negative both in developed and emerging countries supporting free cash flow theory (Jensen, 1986). When companies generate more than necessary cash flow, managers have the tendency to undertake negative NPV projects, resulting in an upsurge in agency problems and so reduced levels of firm value. Moreover, generating excess cash flow may also be observed as an opportunity cost, because a company could pass up positive NPV projects in order to have the ample cash flow, which would ultimately detract from firm value.

Moreover, investments positively contribute to firm value in developed and emerging markets, as investments are a proxy for firms' growth opportunities, and a company with more growth opportunities tends to be valued at a premium by investors. Leverage also positively and significantly affects value of companies both in developed and emerging countries; conforming to free cash flow theory of Jensen (1986). Increased levels of debt creates discipline and becomes an external monitoring tool within the company such that it stops self-interested managers from making future cash payouts to sub-optimal projects, reducing agency costs and therefore increasing firm value. The rise in leverage also brings tax advantages; which improves profitability and consequently value of firms.

The effect of cash ratio on value of companies is negative in developed countries, because excess reserves of cash may result in agency problems between shareholders and managers, with managers investing improvidently in ineffective ventures for the purpose of gaining nonpecuniary benefits while shareholders' wealth and firm value decreases (Jensen \& Meckling, 1976). In contrast, cash ratio positively affects firm value in emerging countries, because ample cash could be perceived as liquidity for the company, which would avoid unpredicted events, 
Table 7. Firm value model: Baseline regressions - Emerging countries

\begin{tabular}{|c|c|c|c|c|c|c|}
\hline $\begin{array}{l}\text { Dep Var: Firm } \\
\text { Value }_{t}\end{array}$ & $\begin{array}{l}(1) \\
\text { FF2 }\end{array}$ & $\begin{array}{l}(2) \\
\text { FF3 }\end{array}$ & $\begin{array}{l}(3) \\
\text { FF4 }\end{array}$ & $\begin{array}{l}(4) \\
\text { FF5 }\end{array}$ & $\begin{array}{l}(5) \\
\text { FF3 }\end{array}$ & $\begin{array}{l}(6) \\
\text { FF3 }\end{array}$ \\
\hline \multirow{2}{*}{ Firm Value $_{(t-1)}$} & $0.414^{* * *}$ & $0.450^{* * *}$ & $0.410^{* * *}$ & $0.400^{* * *}$ & $0.498^{* * *}$ & $0.518^{\star * *}$ \\
\hline & {$[0.000]$} & {$[0.000]$} & {$[0.000]$} & {$[0.000]$} & {$[0.000]$} & {$[0.000]$} \\
\hline \multirow{2}{*}{ Firm Size } & $0.012^{\star *}$ & $0.014^{\star * \star}$ & $0.020^{\star \star *}$ & $0.021^{\star * *}$ & $0.020^{\star * \star}$ & $0.020^{\star * *}$ \\
\hline & {$[0.030]$} & {$[0.003]$} & {$[0.000]$} & {$[0.000]$} & {$[0.000]$} & {$[0.000]$} \\
\hline \multirow{2}{*}{ Cash Flow } & $-0.272^{\star \star \star}$ & $-0.302^{\star \star \star}$ & $-0.326^{\star * *}$ & $-0.338^{* * *}$ & $-0.313^{\star * *}$ & $-0.320^{\star * *}$ \\
\hline & {$[0.000]$} & {$[0.000]$} & {$[0.000]$} & {$[0.000]$} & {$[0.000]$} & {$[0.000]$} \\
\hline \multirow{2}{*}{$\begin{array}{l}\text { Dividend } \\
\text { Dummy }\end{array}$} & $0.022^{\star * *}$ & $0.021^{\star * \star}$ & $0.021^{\star * *}$ & $0.023^{* * *}$ & $0.021^{* \star *}$ & $0.017^{* * *}$ \\
\hline & {$[0.000]$} & {$[0.000]$} & {$[0.000]$} & {$[0.000]$} & {$[0.000]$} & {$[0.000]$} \\
\hline \multirow{2}{*}{ Investment } & $0.068^{\star * *}$ & $0.062^{\star * \star}$ & $0.065^{* * *}$ & $0.083^{* * *}$ & $0.070^{* * *}$ & $0.069^{* * *}$ \\
\hline & {$[0.002]$} & {$[0.004]$} & {$[0.004]$} & {$[0.000]$} & {$[0.001]$} & {$[0.001]$} \\
\hline \multirow{2}{*}{ Leverage } & $0.750^{\star * \star}$ & $0.710^{\star \star \star}$ & $0.698^{\star * \star}$ & $0.700^{\star \star \star}$ & $0.562^{\star \star \star *}$ & $0.523^{\star * *}$ \\
\hline & {$[0.000]$} & {$[0.000]$} & {$[0.000]$} & {$[0.000]$} & {$[0.000]$} & {$[0.000]$} \\
\hline \multirow{2}{*}{ Cash Ratio } & $0.242^{\star * *}$ & $0.221^{*}$ & $0.301^{\star \star}$ & $0.296^{* * *}$ & 0.104 & $0.084^{* * *}$ \\
\hline & {$[0.000]$} & {$[0.076]$} & {$[0.011]$} & {$[0.007]$} & {$[0.002]$} & {$[0.009]$} \\
\hline \multirow{2}{*}{ Firm Age } & -0.010 & -0.010 & -0.004 & -0.005 & 0.006 & 0.008 \\
\hline & {$[0.133]$} & {$[0.158]$} & {$[0.590]$} & {$[0.497]$} & {$[0.213]$} & {$[0.272]$} \\
\hline \multirow{2}{*}{ FF Dummy } & $0.186^{* \star \star}$ & $0.196^{* *}$ & $0.169^{*}$ & $0.262^{*}$ & $0.247^{* *}$ & $0.057^{\star}$ \\
\hline & {$[0.004]$} & {$[0.011]$} & {$[0.086]$} & {$[0.090]$} & {$[0.023]$} & {$[0.056]$} \\
\hline \multirow{2}{*}{$\begin{array}{l}\text { FF Dummy } \times \\
\text { Firm Size }\end{array}$} & & & & & $-0.040^{* *}$ & \\
\hline & & & & & {$[0.018]$} & \\
\hline \multirow{2}{*}{$\begin{array}{l}\text { FF Dummy } \times \\
\text { Firm Age }\end{array}$} & & & & & & $-0.022^{\star *}$ \\
\hline & & & & & & {$[0.043]$} \\
\hline Observations & 8.883 & 8.732 & 8.550 & 8.318 & 8.732 & 8.732 \\
\hline No. of firms & 1.127 & 1.127 & 1.127 & 1.127 & 1.127 & 1.127 \\
\hline $\begin{array}{l}\text { No. of } \\
\text { instruments }\end{array}$ & 68 & 67 & 66 & 65 & 69 & 296 \\
\hline $\mathrm{AR}(1)$ & 0.000 & 0.000 & 0.000 & 0.000 & 0.000 & 0.000 \\
\hline $\mathrm{AR}(2)$ & 0.180 & 0.242 & 0.193 & 0.130 & 0.339 & 0.374 \\
\hline
\end{tabular}

Notes: ${ }^{\star},{ }^{\star *}$ and ${ }^{\star \star \star}$ denote significance at $10 \%, 5 \%$ and $1 \%$, respectively.

protecting the company from uncertainty of cash flow and the costs of liquidity constraints and therefore positively affect value of companies. Moreover, since the movement of capital flows are volatile to a great extent in emerging markets (Bekaert \& Harvey, 2003), companies with higher levels of cash could avoid underinvestment costs by using their own cash, leading to enhanced firm value.

In developed countries, the positive contribution of firm age to value of companies is significant; as investors, particularly in developed countries, put special emphasis on the sustainability of a firm, for which age is one of the indicators. However, age of a company does not significantly impact firm value in emerging countries, signaling that a company's longevity is not an important factor for investors in these countries.

Comparison of the results obtained from developed and emerging firms indicates that, while FF positively affects firm value in both groups, the impact of FF on firm value for emerging countries is greater than the impact in developed countries $(17 \%-26 \%$ for emerging countries vs.
7\%-9\% for developed countries), providing support for Hypothesis 2.

As the last section of baseline tests, I analyze whether firms' size and age moderates the association between FF and firm value, which I analyze with interaction terms (FF $\mathrm{x}$ Firm Size and FF x Firm Age). The findings are shown in Columns 5 and 6 of Table 6 and 7, for developed and emerging countries respectively.

The coefficients of the interactions terms in all four regressions are significantly negative demonstrating that as a firm gets bigger and older, FF's impact on firm value declines, in line with Hypothesis 3 and 4 . As a firm gets bigger or older, information asymmetries are expected to decline and it becomes easier for the company to find other sources of flexibility. Hence in terms of its impact on firm value, being $\mathrm{FF}$ is not as important to larger and older companies as it is to smaller and younger companies. For smaller and younger companies, the impact of FF on value of companies is expected to be stronger in comparison to larger and older companies. 
All in all, this study presents new findings regarding the extent of the impact of FF on firm value. While the effect of FF on firm value is significantly positive both in developed and in emerging countries, this study demonstrates unprecedented findings that the impact of FF on firm value is much higher in emerging countries than in developed countries. Moreover, to the best of our knowledge, for the first time, this study presents unprecedented findings that size and age of a company negatively moderate the relationship between FF and firm value, such that as the size of a company gets bigger and as a company gets older, the magnitude of the impact FF has on firm value drops, i.e. being FF is more significant for smaller and younger companies in terms of increasing their firm value.

A potential problem in GMM is the inclusion of too many instruments in models, which can cause endogenous variables to be over-fitted and hence fail to remove their endogenous components. In GMM, instruments are deemed as too many, if the number of instruments exceeds the number of cross-sectional units. In all models implemented within this study, the number of instruments is less than the cross-sectional units, hence this potential problem does not exist within the context of this analysis. In GMM, to assess whether the instruments used in the model are legitimate and so the model is correctly specified, I use the test for second-order serial correlation of the residuals in the differenced equation $(\operatorname{AR}(2))$, which provides a test on the specification and legitimacy of the variables dated $\mathrm{t}-2$ as instruments in the difference equation. A potential problem with GMM is related to significance level of $\operatorname{AR}(2)$ statistics, because if the $\operatorname{AR}(2)$ statistic is significant, it implies that there is second-order serial autocorrelation in the specified models and hence the models are not valid. AR(2) statistics are insignificant in all of the GMM regressions presented above. Hence the instruments included in the models are valid and model specifications are correct.

\subsection{Robustness tests}

Several additional estimations are conducted to verify the robustness of the baseline tests' findings.

\subsubsection{Different FF definitions}

Initially I implement a stricter definition of FF. In the baseline models presented in Table 6 and Table 7, the deviation within actual leverage and predicted leverage was required to be at least $5 \%$. As a robustness test, the deviation needs to be at least $10 \%$, implying it is harder for companies to become FF. Accordingly, I build four new

Table 8. Robustness tests: Alternative definitions of FF - developed countries

\begin{tabular}{|c|c|c|c|c|c|}
\hline $\begin{array}{c}\text { Dep Var: } \\
\text { Firm Value }_{\mathrm{t}}\end{array}$ & $\begin{array}{c}\mathrm{FF} 2 \\
(10 \%)\end{array}$ & $\begin{array}{c}\text { FF3 } \\
(10 \%)\end{array}$ & $\begin{array}{l}\text { FF4 } \\
(10 \%)\end{array}$ & $\begin{array}{c}\text { FF5 } \\
(10 \%)\end{array}$ & $\begin{array}{c}\mathrm{FF} \\
\text { (always flexible) }\end{array}$ \\
\hline \multirow{2}{*}{ Firm Value $_{(t-1)}$} & $0.423^{\star * *}$ & $0.426^{\star * *}$ & $0.418^{\star * *}$ & $0.414^{\star \star \star}$ & $0.423^{* * *}$ \\
\hline & {$[0.000]$} & {$[0.000]$} & {$[0.000]$} & {$[0.000]$} & {$[0.000]$} \\
\hline \multirow{2}{*}{ Firm Size } & $0.021^{\star * *}$ & $0.021^{\star * *}$ & $0.022^{\star * *}$ & $0.022^{\star * *}$ & $0.024^{\star * \star}$ \\
\hline & {$[0.000]$} & {$[0.000]$} & {$[0.000]$} & {$[0.000]$} & {$[0.000]$} \\
\hline \multirow{2}{*}{ Cash Flow } & $-0.384^{\star \star \star}$ & $-0.387^{\star * \star}$ & $-0.384^{\star \star \star}$ & $-0.402^{\star \star \star}$ & $-0.399^{* * *}$ \\
\hline & {$[0.000]$} & {$[0.000]$} & {$[0.000]$} & {$[0.000]$} & [0.000] \\
\hline \multirow{2}{*}{ Dividend Dummy } & $0.034^{\star * *}$ & $0.036^{\star * *}$ & $0.035^{\star * *}$ & $0.037^{\star * *}$ & $0.031^{\star * *}$ \\
\hline & {$[0.000]$} & {$[0.000]$} & {$[0.000]$} & {$[0.000]$} & {$[0.000]$} \\
\hline \multirow{2}{*}{ Investment } & $0.056^{* * *}$ & $0.058^{\star * *}$ & $0.052^{\star * *}$ & $0.052^{* * *}$ & $0.060^{\star \star \star}$ \\
\hline & {$[0.002]$} & {$[0.001]$} & {$[0.004]$} & {$[0.005]$} & {$[0.001]$} \\
\hline \multirow{2}{*}{ Leverage } & $0.600^{\star * *}$ & $0.600^{* * *}$ & $0.606^{\star * *}$ & $0.608^{\star * *}$ & $0.594^{\star * *}$ \\
\hline & {$[0.000]$} & {$[0.000]$} & {$[0.000]$} & {$[0.000]$} & {$[0.000]$} \\
\hline \multirow{2}{*}{ Cash Ratio } & $-0.142^{\star * \star}$ & $-0.137^{\star \star \star}$ & $-0.134^{\star * \star}$ & $-0.140^{\star * \star}$ & $-0.137^{* * *}$ \\
\hline & {$[0.000]$} & {$[0.000]$} & {$[0.000]$} & {$[0.000]$} & {$[0.000]$} \\
\hline \multirow{2}{*}{ Firm Age } & $0.017^{\star \star \star}$ & $0.016^{\star * *}$ & $0.014^{\star * *}$ & $0.015^{\star * *}$ & $0.011^{\star * *}$ \\
\hline & {$[0.000]$} & {$[0.000]$} & {$[0.000]$} & {$[0.000]$} & {$[0.001]$} \\
\hline \multirow{2}{*}{ FF Dummy } & $0.075^{\star \star *}$ & $0.080^{\star \star}$ & $0.087^{\star * *}$ & $0.082^{\star \star \star}$ & $0.101^{\star * \star}$ \\
\hline & {$[0.000]$} & {$[0.035]$} & {$[0.008]$} & {$[0.006]$} & {$[0.000]$} \\
\hline Observations & 29.249 & 28.006 & 26.702 & 25.289 & 29.249 \\
\hline No. of firms & 2.475 & 2.474 & 2.473 & 2.472 & 2.475 \\
\hline No. of instruments & 181 & 257 & 319 & 235 & 155 \\
\hline $\operatorname{AR}(1)$ & 0.000 & 0.000 & 0.000 & 0.000 & 0.000 \\
\hline $\mathrm{AR}(2)$ & 0.410 & 0.180 & 0.191 & 0.231 & 0.432 \\
\hline
\end{tabular}

Notes: ${ }^{\star},{ }^{\star \star}$ and ${ }^{\star \star \star}$ denote significance at $10 \%, 5 \%$ and $1 \%$, respectively. 
versions of the flexibility dummy (FF2-10\%, FF3-10\%, FF4-10\% and FF5-10\%). The first four columns of Table 8 and Table 9 report the results for developed and emerging countries, respectively.

Using the new definitions of FF, it is observed that the effect on value of companies is greater: impact of new FF dummy (FF2-10\%, FF3-10\%, FF4-10\% and FF5-10\%) on firm value is greater than the impact in baseline regressions both in developed and in emerging countries: Effect of FF3-10\% dummy on value of companies is $8.0 \%$ compared to the $7.6 \%$ impact of FF3-5\% dummy in developed countries and the effect of FF3-10\% dummy on firm value is $20.4 \%$ compared to the $19.6 \%$ impact of FF3-5\% dummy on value of companies in emerging countries. The results for FF2, FF4 and FF5 are similar to these findings.

As another robustness test, I define a firm as FF if the company's observed leverage is always less than the predicted leverage for the 17 years of observations (FF-always flexible). The findings are reported in the fifth column in Table 8 and Table 9, for developed and emerging countries, respectively. Impact of "FF-always flexible" on firm value is bigger in comparison to the other versions of FF both for developed and emerging countries, implying that keeping low leverage for longer periods is beneficial for companies in terms of an upsurge in their value.

\subsubsection{Cash holding policy}

Arslan-Ayaydin et al. (2014) argue that besides maintaining low levels of leverage, companies may also become financially flexible through other ways and maintaining more cash is one of them. In order to take cash into consideration, I include cash holdings as a control variable in all of the leverage specifications, following Ferrando et al. (2017). Hence, my results are based on a FF dummy that already captures the effects of the cash level of the firm. Nevertheless, I run two separate tests to further analyze if the findings from the baseline tests are affected by the cash holdings of a company. First, instead of using total debt, I subtract cash from total debt to find "leverage net of cash" following the methodology implemented by Bates et al. (2009). Then, the leverage model (Model 1) is reestimated to categorize the firms as FF or not, based on which a new variable is created (net leverage). Following this, firm value model (Model 2) is re-run. The first and third columns in Table 10 report the results for the developed and emerging countries, respectively. In both estimations, the association between FF and firm value is significantly positive.

As another robustness test, I re-run the leverage model (Model 1) without including "cash" as a control variable

Table 9. Robustness tests: Alternative definitions of FF - emerging countries

\begin{tabular}{|c|c|c|c|c|c|}
\hline $\begin{array}{c}\text { Dep Var: } \\
\text { Firm Value }_{t}\end{array}$ & $\begin{array}{c}\text { FF2 } \\
(10 \%)\end{array}$ & $\begin{array}{c}\text { FF3 } \\
(10 \%)\end{array}$ & $\begin{array}{c}\text { FF4 } \\
(10 \%)\end{array}$ & $\begin{array}{l}\text { FF5 } \\
(10 \%)\end{array}$ & $\begin{array}{c}\mathrm{FF} \\
\text { (always flexible) }\end{array}$ \\
\hline \multirow{2}{*}{ Firm Value $_{(t-1)}$} & $0.423^{* * *}$ & $0.439^{* * *}$ & $0.416^{* * *}$ & $0.420^{* * *}$ & $0.559^{\star * *}$ \\
\hline & {$[0.000]$} & {$[0.000]$} & {$[0.000]$} & {$[0.000]$} & {$[0.000]$} \\
\hline \multirow{2}{*}{ Firm Size } & $0.010^{*}$ & $0.015^{* * *}$ & $0.020^{* * *}$ & $0.021^{* * *}$ & $0.020^{\star * *}$ \\
\hline & {$[0.081]$} & {$[0.001]$} & {$[0.000]$} & {$[0.000]$} & {$[0.000]$} \\
\hline \multirow{2}{*}{ Cash Flow } & $-0.273^{\star \star \star *}$ & $-0.302^{* * *}$ & $-0.323^{\star * *}$ & $-0.344^{\star * *}$ & $-0.337^{\star * *}$ \\
\hline & {$[0.000]$} & {$[0.000]$} & [0.000] & [0.000] & [0.000] \\
\hline \multirow{2}{*}{ Dividend Dummy } & $0.023^{\star * *}$ & $0.022^{\star * *}$ & $0.022^{\star * *}$ & $0.022^{\star * *}$ & $0.023^{* * *}$ \\
\hline & {$[0.000]$} & {$[0.000]$} & {$[0.000]$} & {$[0.000]$} & {$[0.000]$} \\
\hline \multirow{2}{*}{ Investment } & $0.068^{\star * *}$ & $0.061^{* * *}$ & $0.064^{* * *}$ & $0.085^{\star * *}$ & $0.093^{\star * *}$ \\
\hline & {$[0.002]$} & {$[0.005]$} & {$[0.004]$} & {$[0.000]$} & {$[0.000]$} \\
\hline \multirow{2}{*}{ Leverage } & $0.778^{\star * *}$ & $0.721^{\star * *}$ & $0.701^{\star * \star}$ & $0.684^{\star * *}$ & $0.545^{* * *}$ \\
\hline & {$[0.000]$} & {$[0.000]$} & {$[0.000]$} & {$[0.000]$} & {$[0.000]$} \\
\hline \multirow{2}{*}{ Cash Ratio } & $0.245^{\star}$ & $0.238^{\star}$ & $0.297^{\star *}$ & $0.265^{\star *}$ & $0.088^{\star \star}$ \\
\hline & {$[0.062]$} & {$[0.072]$} & {$[0.015]$} & {$[0.017]$} & {$[0.014]$} \\
\hline \multirow{2}{*}{ Firm Age } & -0.012 & -0.009 & -0.006 & -0.006 & -0.010 \\
\hline & {$[0.100]$} & {$[0.201]$} & [0.445] & {$[0.450]$} & {$[0.239]$} \\
\hline \multirow{2}{*}{ FF Dummy } & $0.219^{* * *}$ & $0.204^{\star *}$ & $0.192^{\star}$ & $0.286^{\star}$ & $0.341^{\star}$ \\
\hline & {$[0.002]$} & {$[0.014]$} & [0.067] & [0.093] & {$[0.076]$} \\
\hline Observations & 8.883 & 8.732 & 8.550 & 8.318 & 29.249 \\
\hline No. of firms & 1.127 & 1.127 & 1.127 & 1.127 & 2.475 \\
\hline No. of instruments & 68 & 67 & 66 & 65 & 155 \\
\hline $\operatorname{AR}(1)$ & 0.000 & 0.000 & 0.000 & 0.000 & 0.000 \\
\hline $\mathrm{AR}(2)$ & 0.178 & 0.226 & 0.201 & 0.151 & 0.432 \\
\hline
\end{tabular}

Notes: ${ }^{*},{ }^{* *}$ and ${ }^{* *}$ denote significance at $10 \%, 5 \%$ and $1 \%$, respectively. 
Table 10. Cash holding policy

\begin{tabular}{|c|c|c|c|c|}
\hline \multirow[b]{2}{*}{ Dep Var: Firm Value ${ }_{t}$} & \multicolumn{2}{|c|}{ Developed Countries } & \multicolumn{2}{|c|}{ Emerging Countries } \\
\hline & $\begin{array}{c}\text { FF3 } \\
\text { (Leverage net of cash) }\end{array}$ & $\begin{array}{c}\text { FF3 } \\
\text { (High cash holding) }\end{array}$ & $\begin{array}{c}\text { FF3 } \\
\text { (Leverage net of cash) }\end{array}$ & $\begin{array}{c}\text { FF3 } \\
\text { (High cash holding) }\end{array}$ \\
\hline \multirow{2}{*}{ Firm Value $_{(t-1)}$} & $0.418^{\star * *}$ & $0.400^{\star * *}$ & $0.684^{* * *}$ & $0.652^{* * *}$ \\
\hline & {$[0.000]$} & {$[0.000]$} & {$[0.000]$} & {$[0.000]$} \\
\hline \multirow{2}{*}{ Firm Size } & $0.010^{\star *}$ & $0.014^{\star * *}$ & $0.007^{\star *}$ & $0.008^{\star * *}$ \\
\hline & {$[0.014]$} & {$[0.000]$} & {$[0.039]$} & {$[0.004]$} \\
\hline \multirow{2}{*}{ Cash Flow } & $-0.356^{\star * *}$ & $-0.335^{\star * \star}$ & $-0.382^{\star * \star}$ & $-0.365^{\star \star \star}$ \\
\hline & {$[0.000]$} & {$[0.000]$} & {$[0.000]$} & {$[0.000]$} \\
\hline \multirow{2}{*}{ Dividend Dummy } & $0.027^{\star * *}$ & $0.035^{\star * *}$ & $0.026^{* * *}$ & $0.027^{\star * *}$ \\
\hline & {$[0.000]$} & {$[0.000]$} & {$[0.000]$} & {$[0.000]$} \\
\hline \multirow{2}{*}{ Investment } & $0.045^{* *}$ & $0.024^{* * *}$ & $0.066^{* * *}$ & $0.080^{* * *}$ \\
\hline & {$[0.013]$} & {$[0.003]$} & {$[0.000]$} & {$[0.000]$} \\
\hline \multirow{2}{*}{ Leverage } & $0.695^{\star * *}$ & $0.774^{\star * *}$ & $0.519^{* * *}$ & $0.433^{* * *}$ \\
\hline & {$[0.000]$} & {$[0.000]$} & {$[0.000]$} & {$[0.000]$} \\
\hline \multirow{2}{*}{ Cash Ratio } & $-0.199^{\star * *}$ & $-0.351^{\star * *}$ & $0.051^{\star * *}$ & $0.090^{* * *}$ \\
\hline & {$[0.000]$} & {$[0.000]$} & {$[0.003]$} & {$[0.000]$} \\
\hline \multirow{2}{*}{ Firm Age } & $0.026^{* * *}$ & $0.015^{\star * *}$ & -0.015 & 0.003 \\
\hline & {$[0.000]$} & {$[0.000]$} & {$[0.121]$} & {$[0.435]$} \\
\hline \multirow{2}{*}{ FF Dummy } & $0.160^{\star * \star}$ & $0.269^{\star * *}$ & $0.153^{\star *}$ & $0.368^{*}$ \\
\hline & {$[0.000]$} & {$[0.000]$} & {$[0.014]$} & {$[0.092]$} \\
\hline Observations & 28.006 & 28.006 & 8.732 & 8.704 \\
\hline No. of firms & 2.474 & 2.474 & 1.127 & 1.120 \\
\hline No. of instruments & 257 & 257 & 85 & 31 \\
\hline $\mathrm{AR}(1)$ & 0.000 & 0.000 & 0.000 & 0.000 \\
\hline $\mathrm{AR}(2)$ & 0.232 & 0.147 & 0.254 & 0.224 \\
\hline
\end{tabular}

Notes: ${ }^{*},{ }^{*}$ and ${ }^{* *}$ denote significance at $10 \%, 5 \%$ and $1 \%$, respectively.

and re-calculate the SDC of firms. However, a company is set as FF if it meets the following two criteria at the same time: $i$. the company has SDC for three consecutive years and ii. In these three consecutive years, the company has above-average industry-adjusted levels of cash. Consequently, a company is considered to be FF, if it has high cash holdings in addition to low leverage (FF3-High cash holding). Finally, I re-run the firm value model (Model 2). The second and fourth columns in Table 10 show the results for these estimations, which are similar to the previous outcomes, demonstrating that the findings obtained in the baseline regressions are robust.

\section{Conclusions}

Financial flexibility is identified as one of the most significant links binding the capital structure theories to the observed behavior of companies, providing explanations for several capital structure puzzles raised in the literature (Marchica \& Mura, 2010; Byoun, 2011, H. DeAngelo \& L. DeAngelo, 2007). Within this context, the first objective of this paper is to quantify FF, and examine its impact on firm value. Another very important goal of this study, is to compare the impact of FF on firm value between developed and emerging countries in Europe, which is done for the first time in the financial flexibility literature, to the best of our knowledge. The final objective of this paper is to comprehend the impact of firm characteristics, encompassing firm age and size, on the association between FF and firm value, which is also done for the first time to the best of our knowledge.

The dataset covers 17 years from 2000 to 2016 for 4.334 companies from 15 developed and 1.436 companies from 6 emerging countries in Europe. I first identify the FF companies in the sample, depending on their low leverage maintenance for a successive number of periods. My findings demonstrate that almost $31 \%$ of the companies in developed countries as opposed to $16 \%$ in emerging countries are FF. Second I investigate if FF has any influence on firm value. I provide empirical evidence that FF enhances firm value in all estimations, supporting the views of Yung et al. (2015) and Gamba and Triantis (2008). The robustness tests, which are conducted with alternative definitions of FF also imply that FF positively and significantly affects firm value. Moreover, with this paper, I provide unprecedented and new evidence that FF's effect on value 
of companies is significantly larger for firms in emerging markets than for firms in developed markets. Finally, I provide novel and unprecedented evidence that company features including firm age and size that proxy for information asymmetries within a firm, negatively moderate the association between FF and value of companies such that the effect of FF on value of companies declines as a firm gets bigger and older.

All in all, surveys conducted with CFOs from all around the world reveal that financial flexibility considerations are very significant in financing decisions. The main findings of this study confirm this result and the positive impact of FF on firm value both in developed and in emerging countries provides solid evidence regarding the fact that financial flexibility should be appreciated by companies all around the world. This is why there are very important managerial implications. First, whether their company is located in a developed or in an emerging country, a manager, should give utmost significance to making their company become and stay financially flexible in their capital structure decisions if they want to surge up their firm value. Furthermore, managers, whose companies are based in emerging countries, should put even more emphasis on their companies' maintenance of FF, since capital markets are relatively less developed and external financing is harder in emerging countries as compared to developed countries, which is why being FF has a stronger impact on firm value for the companies in emerging countries. Last, managers of relatively smaller and younger companies both in developed and emerging countries should also give priority to becoming flexible if they want to improve their firms' value, since the impact of FF on value of companies is considerably higher for these companies.

While this study captures only the publicly quoted companies in Europe, the author aims to extend this empirical analysis in future studies through taking privately held companies into consideration, given the fact that in terms of access to finance a considerable amount of difference is expected to exist between publicly quoted and privately held companies.

\section{Acknowledgements}

There are no acknowledgements.

\section{Funding}

The author has not received any funding for this study.

\section{Author contributions}

This article has been written by one author only.

\section{Disclosure statement}

The author does not have any conflicts of interest.

\section{References}

Aggarwal, R., \& Zhao, X. (2007). The leverage-value relationship puzzle: An industry effects resolution. Journal of Economics and Business, 59(4), 286-297.

https://doi.org/10.1016/j.jeconbus.2006.07.001

Al Ani, M., \& Al Amri, M. (2015). The determinants of capital structure: an empirical study of Omani listed industrial companies. Business: Theory and Practice, 16(2), 159-167. https://doi.org/10.3846/btp.2015.471

Ammann, M., Oesch, D., \& Schmid, M. M. (2011). Corporate governance and firm value: International evidence. Journal of Empirical Finance, 18(1), 36-55.

https://doi.org/10.1016/j.jempfin.2010.10.003

Arellano, M., \& Bond, S. (1991). Some tests of specification for panel data: monte carlo evidence and an application to employment equations. The Review of Economic Studies, 58(2), 277. https://doi.org/10.2307/2297968

Arellano, M., \& Bover, O. (1995). Another look at the instrumental variable estimation of error-components models. Journal of Econometrics, 68(1), 29-51. https://doi.org/10.1016/0304-4076(94)01642-D

Arslan-Ayaydin, O., Florackis, C., \& Ozkan, A. (2014). Financial flexibility, corporate investment and performance: evidence from financial crises. Review of Quantitative Finance and Accounting, 42(2), 211-250. https://doi.org/10.1007/s11156-012-0340-x

Bancel, F., \& Mittoo, U. R. (2004). Cross-country determinants of capital structure choice: a survey of European firms. Financial Management, 103-132. https://doi.org/10.2139/ssrn.683111

Bates, T. W., Kahle, K. M., \& Stulz, R. M. (2009). Why do US firms hold so much more cash than they used to? The Journal of Finance, 64(5), 1985-2021. https://doi.org/10.1111/j.1540-6261.2009.01492.x

Bekaert, G., \& Harvey, C. R. (2003). Emerging markets finance. Journal of Empirical Finance, 10(1-2), 3-55. https://doi.org/10.1016/S0927-5398(02)00054-3

Berger, A. N., \& Udell, G. F. (2005). Small business and debt finance. Handbook of Entrepreneurship Research, 1, 299-328. Springer-Verlag. https://doi.org/10.1007/0-387-24519-7_13

Blundell, R., \& Bond, S. (1998). Initial conditions and moment restrictions in dynamic panel data models. Journal of Econometrics, 87(1), 115-143. https://doi.org/10.1016/S0304-4076(98)00009-8

Bond, S. R., Klemm, A., Newton-Smith, R., Syed, M., \& Vlieghe, G. W. (2004). The roles of expected profitability, Tobin's Q and cash flow in econometric models of company investment. SSRN Electronic Journal. https://doi.org/10.2139/ssrn.641241

Bowsher, C. G. (2002). On testing overidentifying restrictions in dynamic panel data models. Economics Letters, 77(2), 211220. https://doi.org/10.1016/S0165-1765(02)00130-1

Brounen, D., de Jong, A., \& Koedijk, K. (2006). Capital structure policies in Europe: Survey evidence. Journal of Banking \& Finance, 30(5), 1409-1442. https://doi.org/10.1016/j.jbankfin.2005.02.010

Bruno, V. G., \& Claessens, S. (2007). Corporate governance and regulation: can there be too much of a good thing? The World Bank. https://doi.org/10.1596/1813-9450-4140

Byoun, S. (2011). Financial flexibility and capital structure decision. SSRN Electronic Journal. https://doi.org/10.2139/ssrn.1108850 
Chung, K. H., \& Pruitt, S. W. (1994). A simple approximation of Tobin's q. Financial Management, 23(3), 70. https://doi.org/10.2307/3665623

De Jong, A., Verbeek, M., \& Verwijmeren, P. (2012). Des financial flexibility reduce investment distortions? Journal of Financial Research, 35(2), 243-259. https://doi.org/10.1111/j.1475-6803.2012.01316.x

De Miguel, A., Pindado, J., \& De La Torre, C. (2004). Ownership structure and firm value: New evidence from Spain. Strategic Management Journal, 25(12), 1199-1207. https://doi.org/10.1002/smj.430

DeAngelo, H., \& DeAngelo, L. (2007). Capital structure, payout policy, and financial flexibility. SSRN Electronic Journal. https://doi.org/10.2139/ssrn.916093

DeAngelo, H., DeAngelo, L., \& Whited, T. M. (2011). Capital structure dynamics and transitory debt. Journal of Financial Economics, 99(2), 235-261. https://doi.org/10.1016/j.jfineco.2010.09.005

Demir, F. (2009). Volatility of short-term capital flows and private investment in emerging markets. The Journal of Development Studies, 45(5), 672-692. https://doi.org/10.1080/00220380802582379

Denis, D. J. (2011). Financial flexibility and corporate liquidity. Journal of Corporate Finance, 17(3), 667-674. https://doi.org/10.1016/j.jcorpfin.2011.03.006

Denis, D. J., \& McKeon, S. B. (2012). Debt financing and financial flexibility evidence from proactive leverage increases. Review of Financial Studies, 25(6), 1897-1929. https://doi.org/10.1093/rfs/hhs005

Erdogan, S. B. (2019). Financial flexibility and corporate investment: does financial flexibility affect sustainability of firms? The Circular Economy and Its Implications on Sustainability and the Green Supply Chain (pp. 230-245). IGI Global. https://doi.org/10.4018/978-1-5225-8109-3.ch013

Fama, E. F., \& French, K. R. (2005). Financing decisions: who issues stock? Journal of Financial Economics, 76(3), 549-582. https://doi.org/10.1016/j.jfineco.2004.10.003

Faulkender, M., Flannery, M. J., Hankins, K. W., \& Smith, J. M. (2012). Cash flows and leverage adjustments. Journal of Financial Economics, 103(3), 632-646. https://doi.org/10.1016/j.jfineco.2011.10.013

Ferrando, A., Marchica, M.-T., \& Mura, R. (2017). Financial flexibility and investment ability across the Euro Area and the UK: financial flexibility and investment ability. European Financial Management, 23(1), 87-126. https://doi.org/10.1111/eufm.12091

Flannery, M. J., \& Rangan, K. P. (2006). Partial adjustment toward target capital structures. Journal of Financial Economics, 79(3), 469-506. https://doi.org/10.1016/j.jfineco.2005.03.004

Gamba, A., \& Triantis, A. (2008). The value of financial flexibility. The Journal of Finance, 63(5), 2263-2296.

https://doi.org/10.1111/j.1540-6261.2008.01397.x

Graham, J. R., \& Harvey, C. R. (2001). The theory and practice of corporate finance: evidence from the field. Journal of Financial Economics, 60(2-3), 187-243.

https://doi.org/10.1016/S0304-405X(01)00044-7

Jensen, M. (1986). Agency costs of free cash flow, corporate finance, and takeovers. The American Economic Review, 76(2), 323-329.

Jensen, M. C., \& Meckling, W. H. (1976). Theory of the firm: Managerial behavior, agency costs and ownership structure.
Journal of Financial Economics, 3(4), 305-360. https://doi.org/10.1016/0304-405X(76)90026-X

Lemmon, M. L., \& Lins, K. V. (2003). Ownership structure, corporate governance, and firm value: evidence from the East Asian Financial Crisis. The Journal of Finance, 58(4), 14451468. https://doi.org/10.1111/1540-6261.00573

Lemmon, M. L., Roberts, M. R., \& Zender, J. F. (2008). Back to the beginning: persistence and the cross-section of corporate capital structure. The Journal of Finance, 63(4), 1575-1608. https://doi.org/10.1111/j.1540-6261.2008.01369.x

Lonkani, R. (2018). Firm value. Firm Value: Theory and Empirical Evidence, 1. https://doi.org/10.5772/intechopen.77342

Marchica, M.-T., \& Mura, R. (2010). Financial flexibility, investment ability, and firm value: evidence from firms with spare debt capacity. Financial Management, 39(4), 1339-1365.

https://doi.org/10.1111/j.1755-053X.2010.01115.x

Meehan, J., Simonetto, M., Montan, L., \& Goodin, C. (2011). Pricing and profitability management: a practical guide for business leaders. John Wiley \& Sons.

https://doi.org/10.1002/9781119199564

Modigliani, F., \& Miller, M. (1958). The cost of capital, corporation finance and the theory of investment. The American Economic Review, 48(3), 261-297.

Modigliani, F., \& Miller, M. (1961). Dividend policy, growth, and the valuation of shares. The Journal of Business, 34(4), 411-433. https://doi.org/10.1086/294442

Modigliani, F., \& Miller, M. (1963). Corporate income taxes and the cost of capital: a correction. The American Economic Review, 53(3), 433-443.

Myers, S. C. (1977). Determinants of corporate borrowing. Journal of Financial Economics, 5(2), 147-175.

https://doi.org/10.1016/0304-405X(77)90015-0

Myers, S. C. (1984). The capital structure puzzle. The Journal of Finance, 39(3), 574-592.

https://doi.org/10.1111/j.1540-6261.1984.tb03646.x

Myers, S. C., \& Majluf, N. S. (1984). Corporate financing and investment decisions when firms have information that investors do not have. Journal of Financial Economics, 13(2), 187-221. https://doi.org/10.1016/0304-405X(84)90023-0

Pindado, J., De Queiroz, V., \& De La Torre, C. (2010). How do firm characteristics influence the relationship between R\&D and firm value? Financial Management, 39(2), 757-782. https://doi.org/10.1111/j.1755-053X.2010.01091.x

Rapp, M. S., Schmid, T., \& Urban, D. (2014). The value of financial flexibility and corporate financial policy. Journal of Corporate Finance, 29, 288-302.

https://doi.org/10.1016/j.jcorpfin.2014.08.004

Rauh, J. D. (2006). Investment and financing constraints: evidence from the funding of corporate pension plans. The Journal of Finance, 61(1), 33-71. https://doi.org/10.1111/j.1540-6261.2006.00829.x

Wintoki, M. B., Linck, J. S., \& Netter, J. M. (2012). Endogeneity and the dynamics of internal corporate governance. Journal of Financial Economics, 105(3), 581-606. https://doi.org/10.1016/j.jfineco.2012.03.005

Yung, K., Li, D. D., \& Jian, Y. (2015). The value of corporate financial flexibility in emerging countries. Journal of Multinational Financial Management, 32-33, 25-41. https://doi.org/10.1016/j.mulfin.2015.07.001 